\title{
Effects of a willow overstory on planted seedlings in a bottomland restoration
}

\author{
C.J. Dulohery ${ }^{\mathrm{a}, *}$, R.K. Kolka ${ }^{\mathrm{b}}$, M.R. McKevlin ${ }^{\mathrm{c}}$ \\ a Smurfit-Stone Container Corporation, Forest Research Center, P.0. Box 626, Callahan, FL 32011, USA \\ b Department of Forestry, University of Kentucky, Lexington, KY 40546, USA \\ 'Center for Forested W etlands Research, U SD A Forest Service Southern R esearch Station, 2730 Savannah Highway, Charleston, \\ SC 29414, USA
}

Received 19 March 1999; received in revised form 20 May 1999; accepted 7 September 1999

\begin{abstract}
Four bottomland tree species (green ash, bald cypress, water tupelo, and swamp chestnut oak) were planted under four levels of willow canopy (intact canopy, $60 \%$ thinned with herbicide, complete control with herbicide, and complete mechanical removal plus control with herbicide). Through age 5, species selection rather than canopy control treatment was the dominant factor in determining regeneration success. About $55 \%$ of the cypress and green ash seedlings were surviving at age 5, versus 17 and $27 \%$ of water tupelo and swamp chestnut oak, respectively. Green ash was significantly taller (at $3.7 \mathrm{~m}$ ) than all other species at age 5 . The willow canopy provided minor growth benefits during the first 2 years by ameliorating herbaceous competition, hydrology, and soil temperature. However, by age 5 , there were no significant differences in seedling heights among the canopy treatments. We believe that an improved strategy would involve removal of the willow canopy 2 years after planting, when the seedlings begin to exhibit substantial height-growth potential and are, thus, better prepared to respond. (C) 2000 Elsevicr Science B.V. All rights reserved.
\end{abstract}

Keywords: Overstory; Competition; Regeneration; Willow; Cypress; Hardwood; Nurse crop; Transpiration; Diurnal; Water table; Savannah river

\section{Introduction}

Extensive areas of riparian and swamp forest were denuded of vegetation when nuclear reactors at the Savannah River Site discharged heated cooling water into on-site streams (Nelson et al., 2000). Seed sources and living root stocks for all

* Corresponding author. tree species were eliminated from severely impacted areas (Dulohery et al., 1995). Following the cessation of thermal discharge, these areas of bare mineral soil were colonized by light-seeded, early-successional plants, whose seed is readily transported over long distances by wind and animals (Wike et al., 1994; Kolka et al., 1998). Within a few years, a dense overstory comprised primarily of black willow (Salix nigra L.) had developed. 
Prospects for natural regeneration of many tree species were poor. Because cooling water was discharged into the headwaters of Pen branch, surviving trees were located primarily downstream, up to $3 \mathrm{~km}$ from the impacted areas. Adjacent upland forests were composed largely of tree species not adapted to wetland conditions (Wike et al., 1994). Thus, no reasonable vector existed for dispersal of heavy seeds from species such as oak (Quercus spp.), hickory (Carya spp.), and baldcypress (Taxodium distichum (L.) L.C. Rich). Even samaras of species such as green ash (Fraxinus pennsylvanica Marsh.) are transported a relatively short distance by wind. Site surveys conducted from 1988 to 1997 revealed virtually no natural regeneration of heavy-seeded, late-successional tree species in the stream corridor, and only sparse regeneration in the stream delta (Dulohery et al., 1995; Kolka et al., 1998).

Clewell and Lea (1989) described several factors critical to the successful establishment of bottomland hardwood species during restoration, including the remediation of hydrology and the control of competing vegetation. The effect of hydrology on seedling establishment is dependent on both species and the magnitude of changes in soil water (McLeod et al., 1986; Jones et al., 1989). Seedling survival and growth are strongly influenced by the depth, duration, and periodicity of inundation (Conner and Day, 1992; Jones et al., 1994; De Steven and Sharitz, 1997; Keeland and Sharitz, 1997; Keeland et al., 1997; Megonigal et al., 1997). Competing vegetation generally has a negative influence on the survival and growth of seedlings (Jones et al., 1989; Myers et al., 1995).

A dense willow overstory reduces transmittance of light to the forest floor and competes for soil resources. However, overstory trees can also suppress herbaceous competition and moderate temperature and moisture extremes near the soil surface (e.g. Perison et al., 1997). Clewell (1993) suggests that with adequate soil moisture, a willow overstory will actually benefit the early growth of hardwood seedlings. Though the potential benefits of nurse crops are based upon principles of old-field succession, they have not been clearly demonstrated in bottomland forests.
In this study, we will assess four competition control strategies, including leaving the willow overstory in place, complete control, and a treatment of intermediate intensity. Our objectives are to determine the optimum overstory condition for four species of planted bottomland seedlings and to determine the effect of overstory condition on specific microsite factors, which may influence seedling survival and growth.

\section{Methods}

\subsection{Locution}

The Savannah River Site is a US Department of Energy reservation located near Aiken, SC in the upper coastal plain physiographic province. Experimental plots are located in the lower reaches of Four-Mile branch and Pen branch on the Savannah River Site. Four-Mile branch last received significant thermal discharges in 1985 and Pen branch in 1988. The vegetation in Pen branch and Four-Mile branch is similar. The soils in these floodplains are generally classified as fluvaqentic inceptisols, with high spatial variability in characteristics such as texture and organicmatter content. Drainage is very poor.

\subsection{Treatments and design}

Four bottomland tree species, bald cypress (Tuxodium distichum L.), water tupelo (Nyssa aquatica L.), swamp chestnut oak (Quercus michauxii Nutt.), and green ash (Fraxinus pennsylvanica Marsh.), were planted under four levels of competition control in a $4 \times 4$ factorial arrangement of treatments. Species were selected to represent a range of flood and shade tolerances among wetland trees. Competition-control treatments were applied to whole plots, with species in subplots. The design was randomized block, splitplot, with four blocks, each containing one replication of the treatment combinations. Three blocks were located in the Four-Mile corridor and one in the Pen branch corridor.

The four species subplots were adjacent to one another within the whole plot. Each subplot mea- 
sured $3.7 \times 17.4 \mathrm{~m}$ and contained five rows of 20 seedlings planted on a $0.9 \times 0.9 \mathrm{~m}$ spacing. A treated buffer, $9.15 \mathrm{~m}$ in width, was established around the measurement plot to ensure uniform light and competition conditions. The overall treatment plot was 0.13 ha and was selected so that the overstory was initially uniform and dense throughout the plot.

The competition-control treatments were as follows. (1) Control, seedlings were planted under the existing canopy; (2) Intermediate herbicide, $60 \%$ of the overstory basal area was removed by stem injection of herbicide. This treatment was analogous to a partially successful aerial or ground herbicide application; (3) Complete herbicide, all overstory vegetation was removed by stem injection of herbicide, with the stems left in place. This treatment was analogous to a successful aerial or ground herbicide application; (4) Complete mechanical, all overstory vegetation was cut at ground level with a brush cutter or chainsaw and removed from the plot. Stumps were treated with herbicide. This treatment represented the most intensive level of control available.

The herbicide glyphosate $(50 \%$ solution of RodeoTM in water) was used for the stem-injection and stump treatments. Canopy manipulations and planting occurred during the winter of 1993 and 1994. Seedlings were taken from those grown by the Forest Service for the reforestation project (Nelson et al., 2000) and were graded for uniform size before planting. The seed was collected from wild sources in South Carolina.

\subsection{Measurements}

\subsubsection{Seedling estuhlishment and growth}

Heights and survival were recorded in early Spring of 1994-1996, and 1998.

\subsubsection{Herbaceous competition}

Herbaceous competition was measured in $\mathrm{Au}-$ gust, 1994 by placing a $0.25 \mathrm{~m}^{2}$ square on the ground at four random locations within each treatment plot and collecting the above-ground portions of all herbaceous plants rooted within the frame. Samples from the four locations were dried and weighed separately.

\subsubsection{Light transmittance}

Transmittance of photosynthetically active radiation (PAR) was measured during August of 1994 on days with minimal clouding and within $2 \mathrm{~h}$ of solar noon. Plot values were obtained by averaging data collected from six randomly selected points within each plot. PAR was measured with a Licor $^{\mathrm{TM}}$ quantum line sensor positioned at seedling crown height (1 $\mathrm{m}$ above ground). Incident PAR above the canopy was measured simultaneously, permitting calculation of canopy transmittance.

\subsubsection{Water table depth}

Water table depth was measured from September 1994 through September 1995 with shallow wells (about $1 \mathrm{~m}$ in depth) installed in the center of each plot. Depths were recorded at 1-3-h intervals with capacitance probes (Model WL-40, Remote Data Systems).

\subsubsection{Soil temperature}

Soil temperature at a $5-\mathrm{cm}$ depth was recorded on all plots during a period of several weeks in the summer of 1994. Temperatures were recorded 30 times daily using small temperature loggers with an external sensor (Hobo Temperature Logger, Onset Instruments).

\subsection{Data analysis}

All response variables were subjected to analysis of variance, using PROC GLM in SAS (SAS Institute Inc., 1989) and the error allocation dictated by the experimental design. Means were separated with an F-test-protected Duncan's multiple range test. The ANOVA was repeated for each year of available measurements.

A substantial number of trees were lost from some plots due to herbivory by beavers and other sources of mortality. In the analysis of heights, only those subplots with ten or more trees were included. The default method in PROC GLM was used to account for missing cells. Most of the herbivory occurred after planting and prior to initial measurement (before the first growing season), so survival is reported as a percentage of those present during the first measurement. The 
plots were fenced to minimize herbivory after the first measurement.

Diurnal water table fluctuations caused by canopy transpiration were quantified using a SAS program written for this study. The objectives of this program were to identify days when the hydrograph was relatively stable and to calculate the amplitude for those days. The program included the following steps, (1) discard days with incomplete data records; (2) determine minimum and maximum water table values for each day; (3) discard days with any extreme values indicative of storm events or flooding; (4) discard days for which the previous day's data were missing; (5) calculate the difference between the previous and current day minimums; (6) discard days with excessive differences $(>3 \mathrm{~cm})$ between the previous and current day minimums (indicative a rapidly changing base hydrograph); and (7) calculate the diurnal amplitude as current day's maximum minus the average of the two adjacent minimums. The mean amplitude for the growing season of each year (4/15 to $9 / 30$ ) was calculated from these data and used in the ANOVA.

Soil temperatures were obtained with a program in SAS that determined daily minimum, maximum, and average values. These daily values

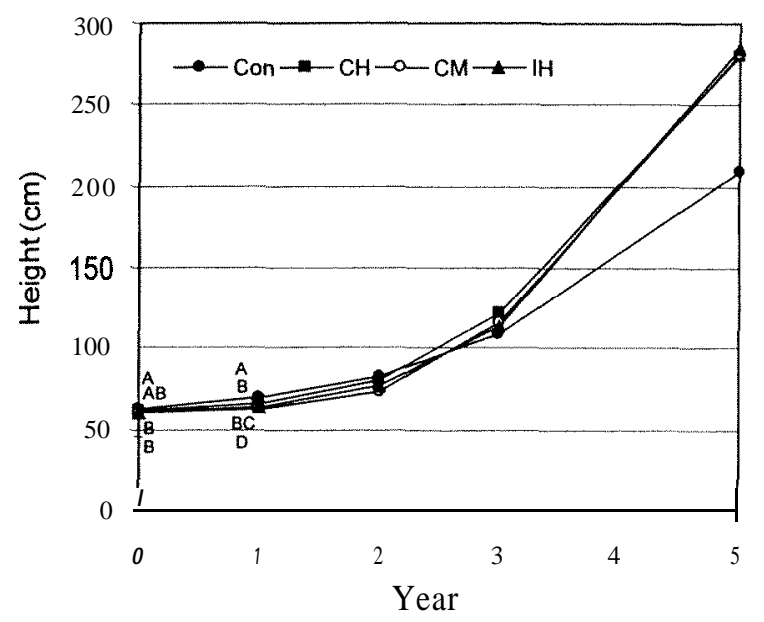

Fig. I. Height trends for each treatment. Con, control; $\mathrm{CH}$, complete herbicide; $\mathrm{CM}$, complete mechanical; III, intermediate herbicide. Significant differences within a year arc indicated by different letters. No significant differences in years $2-5$. were averaged for the period of observation (July 1994) to obtain response variables for the ANOVA.

\section{Results}

\subsection{Seedling performance: treatment effects}

The four species responded similarly to the treatments, i.e. there was no species $\mathrm{x}$ treatment interaction. Therefore, the main effects of treatment and species were examined independently. In the initial measurement (April after planting), heights differed unexpectedly among the treatments (Fig. 1). Initial heights were $63.1 \mathrm{~cm}$ in the controls, $61.8 \mathrm{~cm}$ with complete herbicide, 60.7 $\mathrm{cm}$ with complete mechanical, and $60.2 \mathrm{~cm}$ with intermediate herbicide. Trees in the controls were significantly taller than those in complete mechanical and intermediate herbicide treatments. These initial differences were small, with a range of 2.9 $\mathrm{cm}$, and were probably due to early season height growth.

Significant differences in height-growth increment during the first year seemed to indicate that the willow overstory was serving as a beneficial nurse crop. The control seedlings grew $6.1 \mathrm{~cm}$, almost three times faster than where the overstory was removed $(2.3 \mathrm{~cm})$. Qualitatively, the seedlings in the control plots also appeared healthier and more vigorous during the first year. Height growth increment for the complete herbicide and intermediate herbicide treatments were statistically similar at 4.3 and $3.7 \mathrm{~cm}$, respectively. After the first growing season, seedlings planted under a willow canopy were significantly taller $(69.2 \mathrm{~cm})$ than those in areas where the canopy was removed $(63.1 \mathrm{~cm})$. By the end of the second growing season, however, these early treatment differences had disappeared and were never regained. After the fifth growing season, seedlings in the control plots were shorter than those in all other treatments (Fig. 1), but the difference was not significant $(\mathrm{P}=0.35)$.

At no time did the treatments impact survival significantly (Fig. 2). Mortality accelerated through years 2 and 3 in all treatments and was 


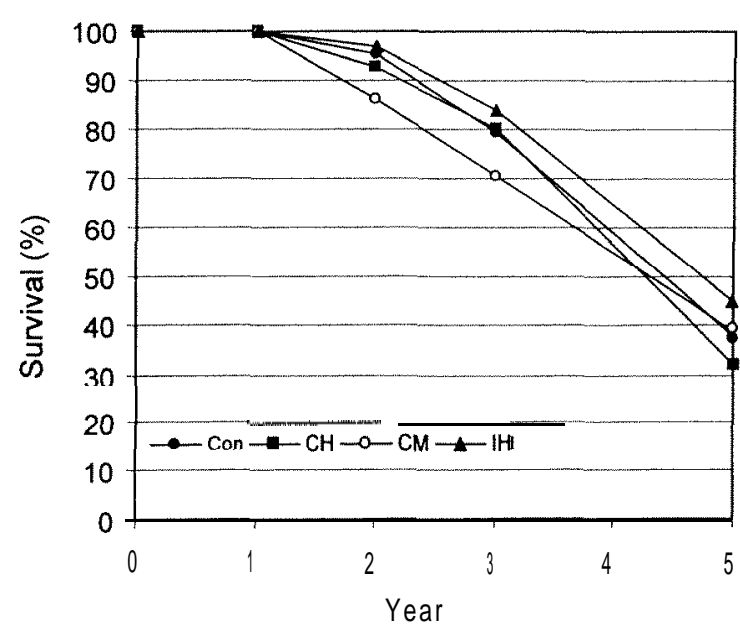

Fig. 2. Survival trends for each treatment. Con, control; $\mathrm{CH}$, complete herbicide; CM, complete mechanical; IH, intermediate herbicide. There were no significant differences among the treatments.

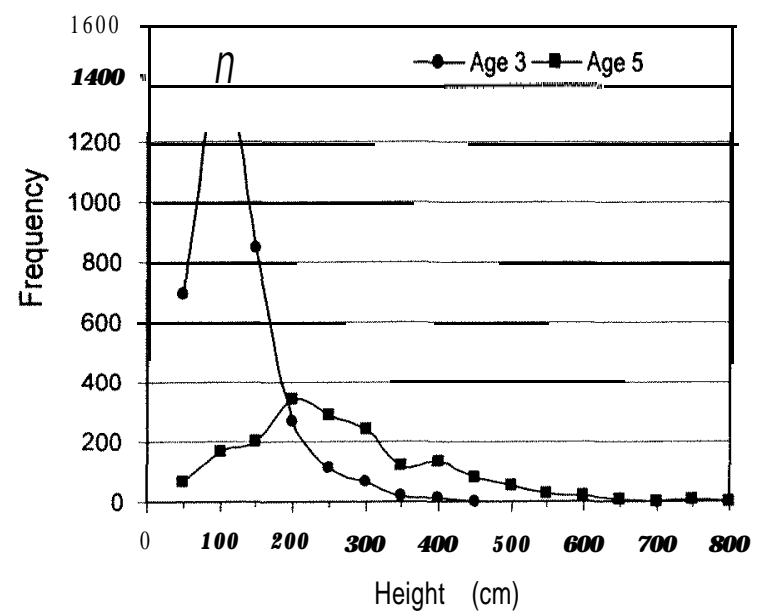

Fig. 3. Frequency distribution (total tree count in each class) of seedling height for all trees in the study at ages 3 and 5. All species are included.

averaging about IO-20\% per year by age 5 , with only $1 / 3-1 / 2$ of the planted seedlings remaining. After year 2, the change in mean height from year-to-year was due both to actual height growth and to excessive mortality among smaller trees. The disproportionate loss of smaller trees is apparent in the ages 3 and 5 frequency distributions for seedling height (Fig. 3). By age 5, only a small percentage of the planted trees appeared to be progressing towards canopy dominance.

\subsection{Seedling performance: species effects}

In contrast to the canopy treatments, species was a strong determinant of growth (Fig. 4) and survival (Fig. 5) through age 5. Initial differences in height among the species were due to the size

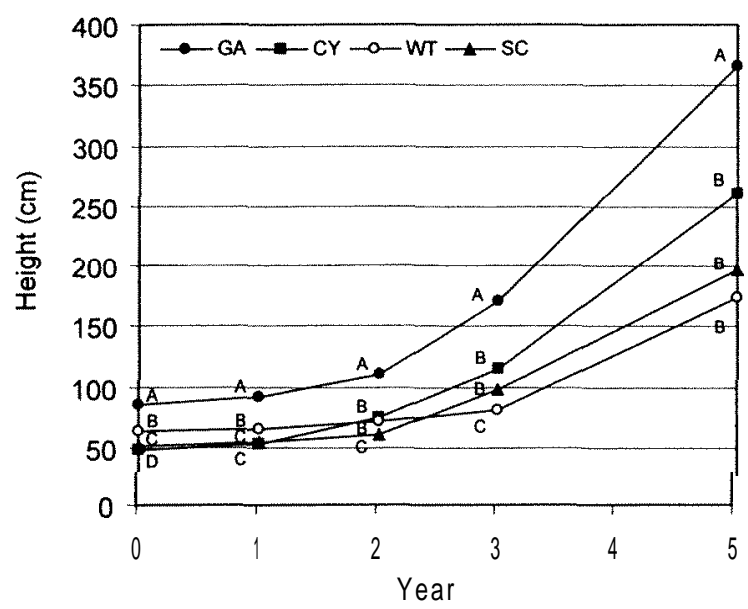

Fig. 4. Height trends for each species. GA, green ash; CY, bald cypress; WT, water tupelo; SC, swamp chestnut oak. Significant differences within a year are indicated by different letters.

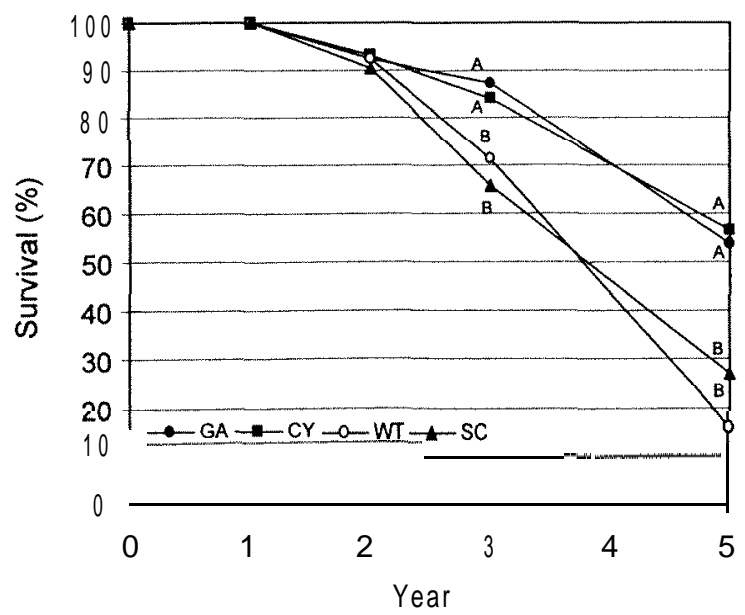

Fig. 5. Survival trends for each species. GA, green ash; CY, bald cypress; WT, water tupelo; SC, swamp chestnut oak. Significant differences within a year are indicated by different letters. 


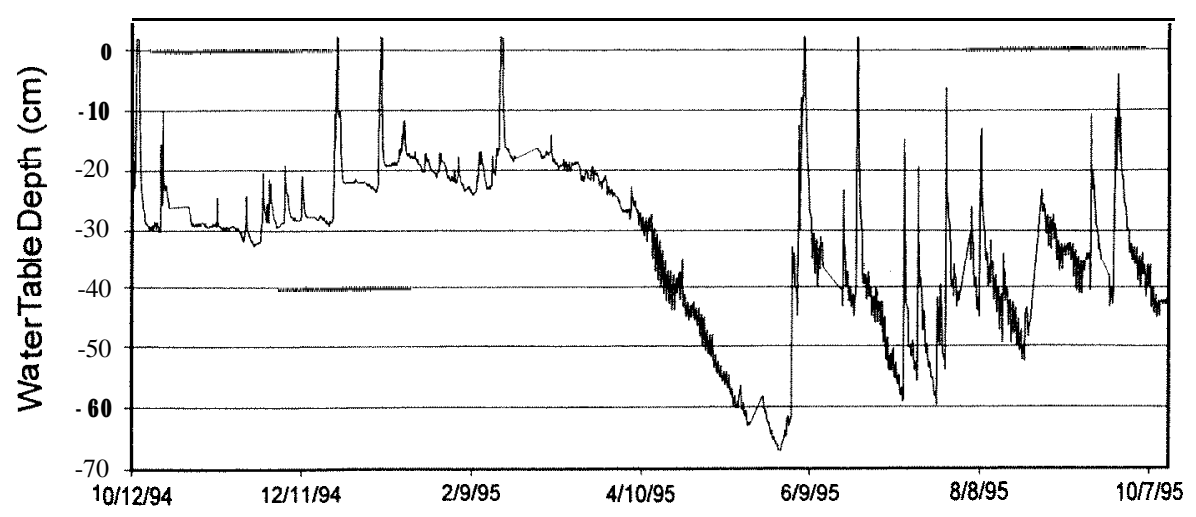

Fig. 6. Hydrograph from plot six located in the Four-Mile creek floodplain. This was one of the better drained plots in the study, and it received the intermediate herbicide treatment. Note that the diurnal water table fluctuations are clearly visible, especially during the 1995 growing season.

they attained in the nursery. For the remainder of the study, however, the species maintained consistent rankings in terms of height growth increment, which were independent of initial height. Green ash grew significantly faster than the other species at all times. Cypress was second, and water tupelo and swamp chestnut oak were the slowest growers.

By age 5, these height growth rankings were reflected in the mean height values. The lack of significant differences among three of the four species at age 5 was probably due both to high variation and missing cells (species subplots) in the analysis. At age 5, the number of cells remaining was 13, 15, 9 and 8 for green ash, cypress, swamp chestnut oak, and water tupelo, respectively. Initially, there were 16 cells for each species (four treatments $\mathrm{x}$ four replications). It should be noted that with an alpha level of 0.1 at age 5, cypress was significantly taller than tupelo.

Over time, the species diverged into two distinct groupings in terms of survival (Fig. 5), with cypress and green ash faring much better than swamp chestnut oak and water tupelo.

\subsection{Seedling environment}

\subsubsection{Hydrology}

Among the plots, average water table depths during the 1994 and 1995 growing seasons were in the range of $0-40 \mathrm{~cm}$, with frequent flooding (e.g. Fig. 6). Thus, even small differences in water table depth represented a relatively large change in available rooting volume. The treatments influenced the magnitude of diurnal water table fluctuations associated with canopy transpiration (Fig. 7). In particular, the intermediate herbicide treatment produced diurnal water table fluctuations that were significantly larger than those of any other treatment during the 1995 growing season.

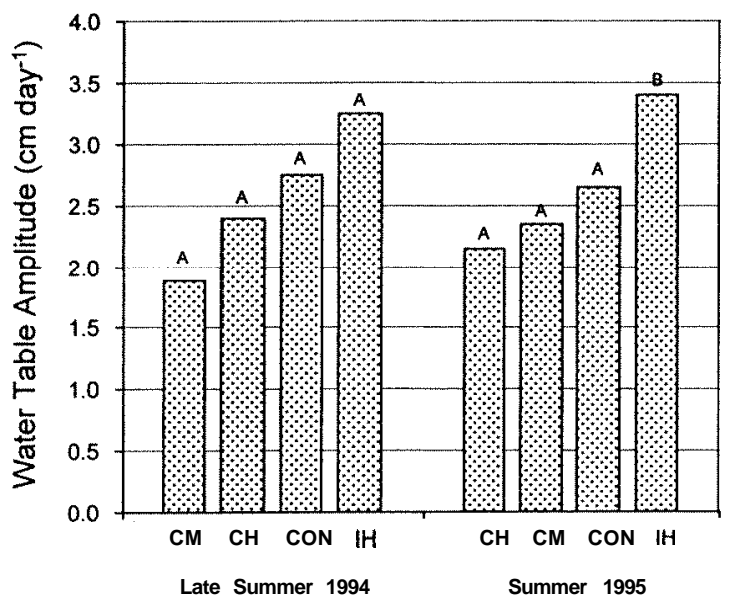

Fig. 7. Treatment effects on diurnal water table fluctuations. Con, control; $\mathrm{CH}$, complete herbicide; $\mathrm{CM}$, complete mechanical; $\mathrm{IH}$, intermediate herbicide. Means with the same letter are statistically similar. 


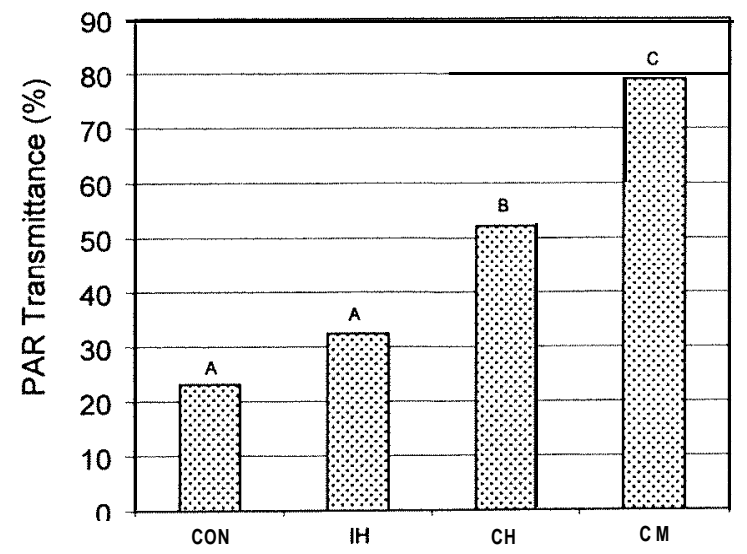

Fig. 8. Transmittance of PAR by treatment in August of year 1, Con, control; $\mathrm{CH}$, complete herbicide; $\mathrm{CM}$, complete mechanical; IH, intermediate herbicide. Means with the same letter are statistically similar.

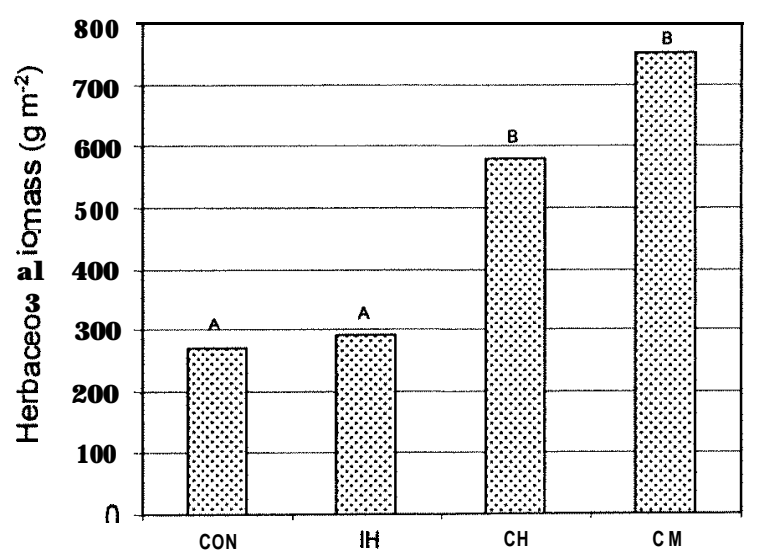

Fig. 9. Treatment effects on herbaceous biomass in August of year 1. Con, control; $\mathrm{CH}$, complete herbicide; $\mathrm{CM}$, complete mechanical; IH, intermediate herbicide. Means with the same letter are statistically similar.

\subsubsection{Light}

Removal of the canopy resulted in significantly higher light availability at the seedling crown level (Fig. 8) and on the forest floor in August of 1994. Partial interception of light in the complete mechanical and complete herbicide treatments resulted from vines, other competing vegetation, standing snags, and/or some minor amounts of residual foliage in the willow crowns. By August of the first year, the canopy had expanded in the intermediate herbicide treatment to the extent that PAR transmittance did not differ significantly from the controls.

\subsubsection{Herbaceous competition}

Herbaceous plants roughly tripled in biomass when the canopy was completely removed (Fig. 9). Where the canopy was aggressively thinned, however, herbaceous biomass was similar to that of the controls by August of the first year.

\subsubsection{Soil temperature}

July soil temperatures in areas with an intact willow canopy were more moderate than where the canopy had been removed (Fig. 10). Average daytime high temperatures at a $5-\mathrm{cm}$ depth were $2.7^{\circ} \mathrm{C}$ lower under a full canopy versus areas with complete canopy removal. The $24 \mathrm{~h}$ average daily temperature of the complete mechanical plots was significantly greater $(P=0.07)$ than that of all other treatments. The morning low temperatures did not differ significantly among the treatments.

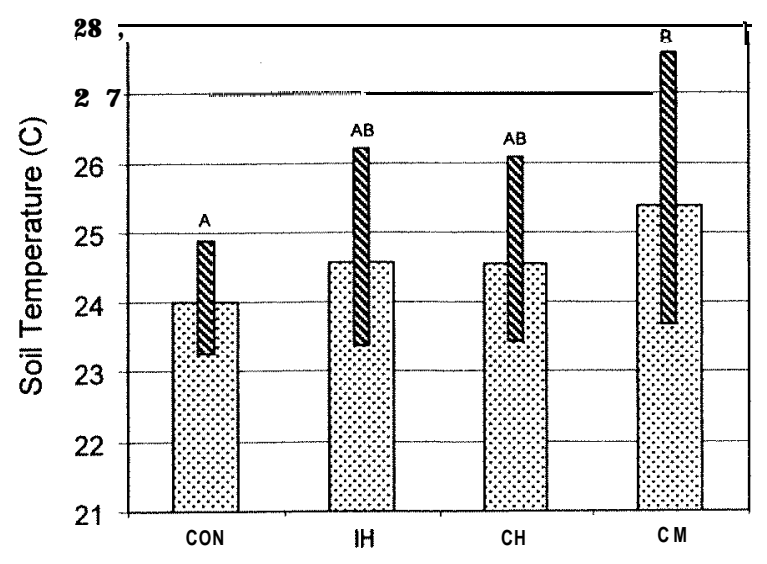

Fig. 10. Treatment effects on average daily soil temperature at a 5 -cm depth in July of year 1 . Small bar shows range, minimum, and maximum. Con, control; $\mathrm{CH}$, complete herbicide; CM, complete mechanical; IH, intermediate herbicide. Bars with the same letter indicate that average daily high temperatures were statistically similar. 


\subsection{Species deployment}

Most obvious among our results was that species selection was the dominant factor in determining success through age 5 . The species that fared best were those exhibiting rapid height growth, flood tolerance, and lower sensitivity to competing vegetation. When planting bare-root seedlings with minimal silvicultural inputs and no hydrologic amelioration, only the hardiest species with a robust tolerance to adverse conditions should be chosen. Green ash and bald cypress appear to be two such species. Species with similar growth characteristics such as cottonwood (Populus deltoides Bart ex. Marsh.), sycamore (Platanus occidentalis L.), tulip poplar (Liriodendron tulipifera L.), and slash pine (Pinus elliottii Engelm.) may also be reasonable candidates for such a planting, depending on a site's location and hydrology.

If attempting to introduce slow growing, late successional trees such as swamp chestnut oak into such an environment, one can expect only a small percentage to grow to maturity. Though highly flood tolerant, water tupelo appeared to be sensitive to shading and competition. In the operational restoration, it has survived much better in the open cattail marshes of the stream delta (Kolka et al., 1999). Water tupelo appears to be a poor choice for the stream floodplain, where there is severe herbaceous competition and a dense overstory.

\subsection{Silvicultural options}

As a silvicultural strategy, removal of the willow overstory before planting was inadequate to impart a significant growth advantage by age 5 . Other constraints on regeneration remained or were actually worsened by canopy removal. Herbaceous competitors proliferated. Soil and, undoubtedly, air temperatures were raised, placing greater respiratory demands on the seedlings. Transpiration by the willow overstory and the consequent lowering of the water table during the day was reduced. In contrast, conditions appeared to be more favorable under a full canopy during the first 2 years. However, when the seedlings reached a stage of rapid height-growth potential (about age 3), the canopy became a limitation to growth. Each treatment tested, including the control, left significant limitations to growth in place, therefore none provided a clear advantage.

Observations of seedling growth phenology and treatment effects on the seedling environment suggest that alternative silvicultural strategies not represented in this study could be more successful. One possibility is a comprehensive system that addresses all major growth limitations by ameliorating hydrology, eliminating woody competition, and suppressing herbaceous competition. This kind of approach has proven consistently successful in commercial conifer and hardwood plantings. In this bottomland environment, however, it would have been necessary to continuously control the beaver population and to enter the stands repeatedly with hand crews during the first 2 years for herbaceous competition control. The use of heavy equipment for bedding or any other purpose was impractical. A comprehensive silvicultural approach to ameliorate all limiting factors was probably infeasible on this site.

A more realistic approach may be to optimize the timing of available treatments. During the first 2 years, our results showed that height--growth potential was minimal. Seedlings were unable to take advantage of the pre-plant canopy removal treatments and, in fact, seemed to benefit from the more moderate conditions under an existing canopy. After 1 and 2 years, seedlings exhibited the potential for rapid height growth. This may be the best time to begin removing the canopy.

We believe that thinning the canopy by stem injection of herbicide after the first or second year is a promising approach, which would create favorable conditions when the seedlings are in a position to respond. The remaining canopy would continue to ameliorate hydrology by lowering the water table during the day. Light availability would be improved, while temperature extremes and herbaceous competition would be moderated. As the seedlings matured and became less sensitive to herbaceous competition, the canopy could be opened further, allowing the target species to capture the site. 
Although it is quite likely that properly timed canopy control treatments will ultimately benefit planted seedlings, any such approach remains speculative. The only strategy strongly supported by our results is deployment of fast growing species that are robust to the range of conditions likely to occur on the site.

\subsection{Environmental characterization}

For many environmental variables, the cost of recording continuous data has been reduced dramatically. It has become possible to instrument many plots in an experiment for continuous observation of multiple variables $m$ and the computing power required to process such data is easily affordable. We generated 77000 observations of water table depth during this study. This is one of the first studies where continuous water table data has been collected on a complete set of experimental plots in a fully replicated study and perhaps the first where the magnitude of diurnal water table fluctuations over an extended period was utilized as an experimental response variable. Even the continuous recording of soil temperature for extended periods on a full set of experimental plots has been rare.

The availability of continuous data allowed us to generate a response variable that represented a dynamic process of clear biological significance (the amplitude of diurnal water table fluctuations associated with canopy transpiration). It is almost certain that, in this system, manual observations of water table depth collected at various times during the day would have revealed no significant differences in mean water table depth. As more low-cost instrumentation becomes available for continuous observation of the physical environment, investigators should consider opportunities to generate response variables that represent dynamic processes, which were previously impractical to characterize.

\section{Conclusions}

1. Species selection was the dominant factor governing regeneration success through age 5 .
Fast growing, widely adaptable species were most successful.

2. The willow canopy provided transitory 'nurse crop' benefits during the first 2 years only. The growth benefits were small and were not sustained beyond the second year.

3. Partial or complete removal of the willow canopy before planting provided no significant advantage in terms of growth or survival through age 5. These treatments produced unfavorable environmental conditions for the early growth of seedlings.

4. An improved approach would take advantage of the early nurse-crop benefits by removing the overstory competition sometime after the second year, when the seedlings have exhibited sufficient height-growth potential to respond quickly to the treatments.

\section{References}

Clewell, A.F., 1993. Do nurse crops facilitate bottomland forest establishment. Wetlands J. 5 (2), 19-20.

Clewell, A.F., Lea, R., 1989. Creation and restoration of forested wetland vegetation in the southeastern United States. In: Kusler, J.A., Kentula, M.E. (Eds.), Wetland Creation and Restoration: The Status of the Science. Island Press, Washington, DC, pp. 195-232.

Conner, W.H., Day, J.W. Jr, 1992. Water level variability and litterfall productivity of forested freshwater wetlands in Louisiana. Am. Midl. Nat. 128, 237-245.

De Steven, D., Sharitz, R.R., 1997. Differential recovery of a deepwater swamp forest across a gradient of disturbance intensity. Wetlands 17 (4), 476-484.

Dulohery. C.J., Bunton, C.S., Trettin, C.C., McKee, W.H., 1995. Reforestation, monitoring, and research at Pen branch: restoring a thermally impacted wetland forest. Establishment Report, USDA Forest Service, FS-6200-7.

Jones, R.H., Sharitz, R.R., McLeod, K.W., 1989. Effects of flooding and root competition on growth of shaded bottomland hardwood seedlings. Am. Midl. Nat. 121, 165 175.

Jones, R.H., Sharitz, R.R., James, S.M., Dixon. P.M., 1994. Tree population dynamics in seven South Carolina mixed species forests. Bull. Torr. Bot. Club 121 (4), 360 -368.

Keeland, B.D., Sharitz, R.R., 1997. The effects of water-level fluctuations on weekly tree growth in a Southeastern USA swamp. Am. J. Bot. 84 (1), 131-139.

Keeland, B.D., Conner, W.H., Sharitz, R.R., 1997. A comparison of wetland tree growth response to hydrologic regime in Louisiana and South Carolina. For. Ecol. Manage. $90,237-250$. 
Kolka, R.K., Nelson, E.A., Bonar, R.E., Dulohery, C.J., Gartner, D., 1998. Forested wetland restoration - the Pen branch project. Restor. Manage. Notes 16 (2), 147-159.

Kolka, R.K., Trettin, C.C., Nelson, E.A., Connor, W.H., 1999. Tree seedling survival across a hydrologic gradient in a bottomland hardwood restoration. Proceedings of the 25th Annual Conference on Ecosystem Restoration and Creation, Hillsborough Community College, Tampa, FL, 89102.

McLeod, K.W., Donovan, L.A., Stumpff, N.J., Sherrod, K.C., 1986. Biomass, photosynthesis, and water use efficiency of woody swamp species subjected to flooding and elevated water temperature. Tree Physiol. 2, 341-346.

Megonigal, J.P., Conner, W.H., Kroeger, S., Sharitz, R.R., 1997. Aboveground production in Southeastern floodplain forests: a test of the subsidy-stress hypothesis. Ecology 78 (2), 370-384.

Myers, R.S., Shaffer, G.P., Llewellyn, D.W., 1995. Baldcypress restoration in southeast Louisiana: the relative effects of herbivory, flooding, competition, and macronutrients. Wetlands 15 (2), 141-148.

Nelson, E.A., Dulohery, C.J., Kolka, R.K., McKee, W.H., 2000. Operational restoration of the Pen branch bottomland hardwood and swamp wetlands ‥m the research setting. Ecol. Eng.

Perison, D., Phelps, J., Pavel, C., Kellison, R., 1997. The effects of timber harvest in a South Carolina blackwater bottomland. For. Ecol. Manage. 90, 171-185.

SAS Institute Inc., 1989. SAS/STAT User's Guide, version 6, fourth ed., vol. 2. SAS Institute Inc., Cary, NC.

Wike, L.D., Shipley, R.W., Bowers, J.A., Bryan, A.L., Cummins, C.L., del Carmen, B.R., Friday, G.P., Irwin, J.E., Mackey Jr., H.E., Mayer, J.J., Nelson, E.A., Paller, M.H., Rogers, V.A., Specht, W.L., Wilde, E.W., 1994. SRS Ecology: Environmental Information Document, Chap. 6, Pen branch Wetland changes, 1987- 1992. Westinghouse Savannah River Company, Savannah River Site, Aiken, SC, USA. 